\section{Pacific Northwest}

National Laboratory

Operated by Battelle for the

U.S. Department of Energy

\title{
Central Energy System Modernization at Fort Jackson, South Carolina
}

\author{
D.R. Brown \\ W.D. Chvala, Jr.
}

J.A. Dirks

November 2006

Prepared for

U.S. Department of Energy

Federal Energy Management Program

and the U.S. Army

Installation Management Agency - Southeast Region under Interagency Agreement AGRMIPR6DPW00002

with the U.S. Department of Energy

under Contract DE-AC05-76RL01830 


\title{
DISCLAIMER
}

This report was prepared as an account of work sponsored by an agency of the United States Government. Neither the United States Government nor any agency thereof, nor Battelle Memorial Institute, nor any of their employees, makes any warranty, express or implied, or assumes any legal liability or responsibility for the accuracy, completeness, or usefulness of any information, apparatus, product, or process disclosed, or represents that its use would not infringe privately owned rights. Reference herein to any specific commercial product, process, or service by trade name, trademark, manufacturer, or otherwise does not necessarily constitute or imply its endorsement, recommendation, or favoring by the United States Government or any agency thereof, or Battelle Memorial Institute. The views and opinions of authors expressed herein do not necessarily state or reflect those of the United States Government or any agency thereof.

\author{
PACIFIC NORTHWEST NATIONAL LABORATORY \\ operated by \\ BATTELLE \\ for the \\ UNITED STATES DEPARTMENT OF ENERGY \\ under Contract DE-AC05-76RL01830
}

Printed in the United States of America

Available to DOE and DOE contractors from the Office of Scientific and Technical Information, P.O. Box 62, Oak Ridge, TN 37831-0062; ph: (865) 576-8401 fax: (865) 576-5728 email: reports@adonis.osti.gov

\footnotetext{
Available to the public from the National Technical Information Service, U.S. Department of Commerce, 5285 Port Royal Rd., Springfield, VA 22161 ph: (800) 553-6847 fax: (703) 605-6900 email: orders@ntis.fedworld.gov online ordering: http://www.ntis.gov/ordering.htm This document was printed on recycled paper.
} 


\title{
Central Energy System Modernization at Fort Jackson, South Carolina
}

\author{
D.R. Brown \\ W.D. Chvala, Jr. \\ J.A. Dirks
}

November 2006

Prepared for

The U.S. Department of Energy

Federal Energy Management Program

and the U.S. Army

Installation Management Agency - Southeast Region

under Interagency Agreement AGRMIPR6DPW00002

with the U.S. Department of Energy

under Contract DE-AC05-76RL01830

Pacific Northwest National Laboratory

Richland, Washington 99352 


\section{Executive Summary}

An evaluation of technology options was conducted for the central energy systems at Fort Jackson, South Carolina. There were two objectives in conducting this study. From a broader viewpoint, the Army would like to develop a systematic approach to management of its central energy systems and selected Fort Jackson for this "pilot” study for a prospective Central Energy System Modernization Program. From a site-specific perspective, the objective was to identify the lowest life-cycle cost energy supply option(s) at Fort Jackson for buildings currently served by central boilers and chillers. This study was co-funded by the Army’s Southeast Region and the U.S. Department of Energy’s Federal Energy Management Program.

Fort Jackson currently has three central energy systems with each system comprised of central boilers and chillers connected to tens of buildings via hot and chilled water distribution piping ${ }^{1}$. The components of each system vary with respect to vintage and condition. The following options were evaluated in this study.

- Continued operation of existing systems with periodic equipment replacements as necessary.

- The replacement of central boilers and hot water distribution piping with building boilers and natural gas piping.

- Central cogeneration of electricity and hot water.

- Self-generation of electricity for peak demand shaving.

- Central chilled water storage.

The economic results of the study are summarized in Table 1. Life-cycle cost effectiveness was determined based on an economic evaluation conducted per current guidelines for Federal energy projects. In short, the present value of savings exceeds the present value of costs for life-cycle cost-effective projects. The payback period is provided as well because of its intuitive appeal as an economic metric.

The replacement of central boilers and hot water distribution piping with building boilers and natural gas piping was cost effective for all central energy systems, but was most cost effective for central energy plant \#2. The economics for plant \#2 are better because it suffers from the greatest thermal losses from its existing thermal distribution system and because its average building boiler size is large, which minimizes the distributed boiler economy-of-scale cost penalty.

Fort Jackson is currently considering replacing failing hot water distribution piping for the hospital area loop coming from central energy plant \#2. Although decentralization of the entire system is recommended, decentralization of the hospital area loop is highly

\footnotetext{
${ }^{1}$ A fourth system was recently constructed to serve several of the more distant buildings previously served by central energy plant \#2. This study is based on the thermal distribution system connections prior to commissioning of the fourth central energy plant.
} 
recommended. Thermal losses per foot are believed to be much greater than average for this older section of the distribution system and distribution piping replacement costs could be immediately avoided via decentralization. Thus, decentralization economics would be better for the hospital area loop than for the rest of the system. In addition, the experience would serve as a test case for further boiler decentralization.

Cogeneration was found to not be cost effective with either combustion turbine or reciprocating engine technologies. These results occurred even when $100 \%$ of the available thermal energy was generously assumed to be utilized. The average cost of electricity is too low and the cost of natural gas too high to make cogeneration economically attractive.

On the other hand, high on-peak electricity demand charges make self-generation for peak shaving a cost-effective option. Multiple single-MW generators are recommended over a single larger generator to minimize the economic risk of an unplanned outage occurring when the peak demand for a month is occurring.

Fort Jackson has an existing chilled water storage system at central energy plant \#2, but it needs repairs to its internal piping to resume operation. These repairs were found to be very cost effective and should be pursued immediately. Installation of new chilled water storage was found to be marginally cost effective at central energy plant \#1 and not cost effective at central energy plant \#3. The economics of chilled water storage suffer at the latter plant because its smaller capacity does not allow the capture of significant economies-of-scale in chilled water storage systems.

Although chilled water storage and peak shaving both aim to reduce on-peak demand, the interactive effects should not be significant. Chilled water storage lowers the electricity demand profile across the on-peak periods, but only moderately flattens the demand profile. Thus, self generation for peak shaving and chill storage should both be cost effective. Nevertheless, examination of historical hourly electric load profiles would be required to develop a peak shaving generator dispatch strategy and should consider the potential impacts of chill storage.

Table 1. Results Summary

\begin{tabular}{|l|c|c|}
\hline Option & $\begin{array}{c}\text { Life-Cycle } \\
\text { Cost } \\
\text { Effective }\end{array}$ & $\begin{array}{c}\text { Payback } \\
\text { Period, } \\
\text { Years }\end{array}$ \\
\hline $\begin{array}{l}\text { Central Energy Plant (CEP) \#1 Boiler } \\
\text { Decentralization }\end{array}$ & Yes & 9 \\
\hline CEP \#2 Boiler Decentralization & Yes & 4 \\
\hline CEP \#3 Boiler Decentralization & Yes & 8 \\
\hline 5-MW Reciprocating Engine Cogeneration & No & 15 \\
\hline 5- MW Combustion Turbine Cogeneration & No & Infinite \\
\hline 1-MW Reciprocating Engine Peak Shaving & Yes & $7-8$ \\
\hline 5-MW Reciprocating Engine Peak Shaving & Yes & 7 \\
\hline CEP \#1 Chill Storage & Yes & 13 \\
\hline CEP \#2 Chill Storage Repair & Yes & 3 \\
\hline CEP \#3 Chill Storage & No & 21 \\
\hline
\end{tabular}




\section{Contents}

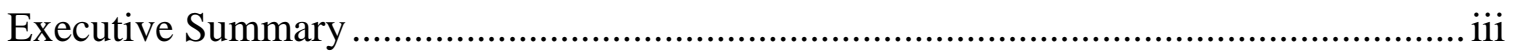

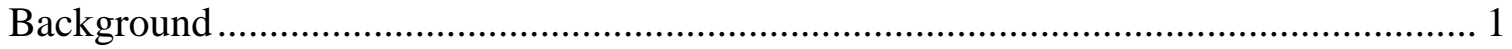

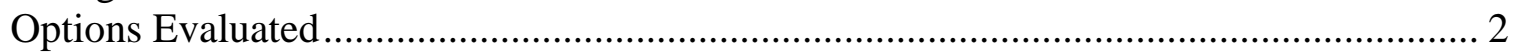

Building and Central Plant Thermal Loads .................................................................... 3

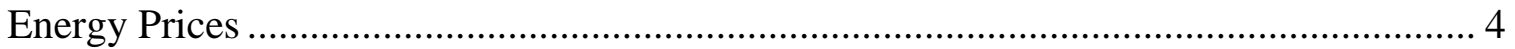

Central Energy System Characteristics.......................................................................... 5

Decentralization of HW Supply for Space and Service Water Heating ............................... 7

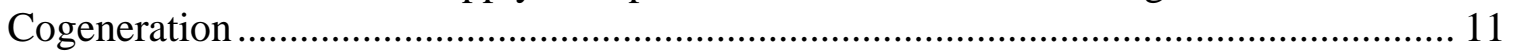

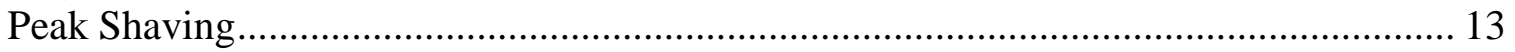

Chill Thermal Energy Storage ..................................................................................... 15

Appendix A Buildings Served by Central Energy Plants .............................................. A.1 


\section{Figures}

Figure 1. Summer 2003 Daily CEP NG Consumption ................................................. 7

\section{Tables}

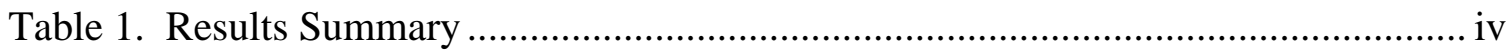

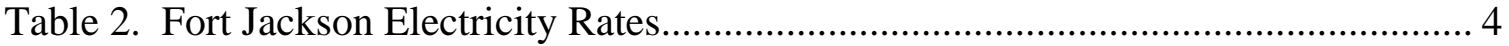

Table 3. Fort Jackson Central Boiler and Chiller Characteristics................................... 5

Table 4. Estimated HW Distribution Thermal Loss Calculations ..................................... 7

Table 5. New Natural Gas Piping Length and Cost........................................................ 8

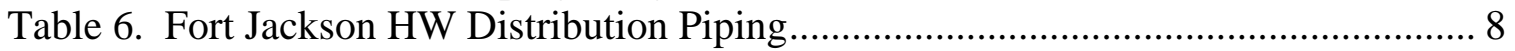

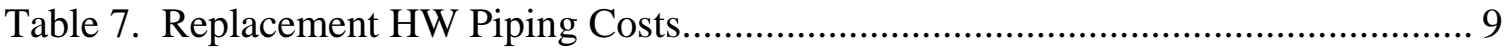

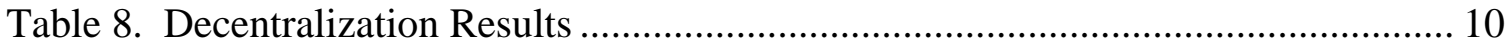

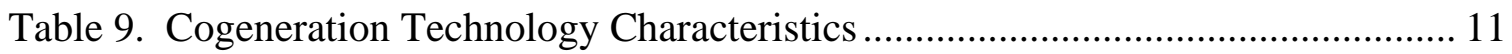

Table 10. Cogeneration Economic Results................................................................... 12

Table 11. Peak Shaving Technology Characteristics................................................. 14

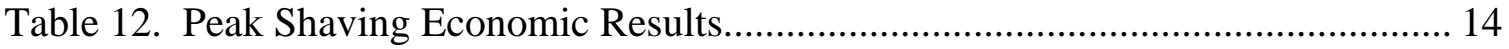

Table 13. CEP Thermal Energy Storage Capacities ..................................................... 16

Table 14. Chill Thermal Energy Storage Annual Electricity Savings ............................ 16

Table 15. Chill Thermal Energy Storage Costs and Economics..................................... 17 


\section{Background}

Central energy systems ${ }^{2}$ (CES) are almost always the single greatest energy consumer at Army installations. Whether providing electricity, hot water, steam, chilled water or some combination of these four products, the choice and management of CES is usually a key to successful energy management of the entire installation.

Fort Jackson currently has four central energy plants providing hot water (HW) and chilled water (CW) to approximately 150 buildings totaling 3.7 million square feet. This represents about $50 \%$ of non-family housing building area at the Fort. A chilled-water storage tank is installed at one of the CEPs. The CEP equipment and thermal distribution piping have been constructed over several decades with periodic replacement of major components. The result is a system with components that range from the brand new and perfectly working to $40+$ years old and seriously deteriorated.

Fort Jackson's central energy systems are thought to be representative of many other Forts that also have one or more central energy systems. As such, Fort Jackson was selected for this pilot study for a prospective Army CES Modernization Program. The study was cofunded by the Army's Southeast Region and the Federal Energy Management Program (FEMP). The Army would like to develop a systematic approach to CES management that considers a broad set of options and implements the option(s) that minimize the life-cycle cost of providing building electricity, space heating, space cooling, and service water heating needs. The specific objective of this study was to identify the least cost option(s) at Fort Jackson for buildings currently served by central boilers and chillers.

\footnotetext{
${ }^{2}$ In this report, a "central energy system” encompasses the "central energy plant,” where central boilers and chillers reside, and the thermal distribution piping (hot water and/or chilled water) connecting central plants with individual buildings.
} 


\section{Options Evaluated}

Pacific Northwest National Laboratory staff visited Fort Jackson in the Fall of 2005 to introduce the study to site staff, discuss options to be evaluated, discuss the evaluation methodology, and collect data to be used in the evaluation. The basic options to be evaluated were as follows.

- Continued operation of existing systems with periodic equipment replacements as necessary.

- The replacement of central boilers and HW distribution piping with building boilers and natural gas piping.

o Immediate or delayed until next major replacement necessary for continued operation.

o Entire system or selected branches/buildings

- Central cogeneration of electricity and hot water.

Supplemental options to be evaluated given site interest and as study resources allowed were as follows.

- Chilled water storage.

- Building boilers for service hot water only.

- Self-generation for peak demand shaving.

- Centralization of CW supply for buildings currently with their own chillers.

- The replacement of central chillers and CW distribution piping with building chillers.

o Immediate or delayed until next major replacement necessary for continued operation.

o Entire system or selected branches/buildings.

Of the supplemental options listed above, Fort Jackson was most interested in examining chilled water storage and self-generation for peak demand shaving. The Fort was also interested in the possible creation of a new CES for providing CW centrally for a group of buildings currently served by individual chillers, but this option was given a lower priority. Finally, the Fort was less interested in considering building boilers for service water heating only or the replacement of central chillers and CW piping with building chillers.

Ultimately, study resources allowed consideration of chilled water storage and selfgeneration for peak demand shaving. 


\section{Building and Central Plant Thermal Loads}

At the core of any assessment of building energy options is the determination of space heating, space cooling, and service hot water loads. These load data set the size and cost of building equipment and the size and cost of central equipment when combined with losses from thermal distribution piping. The loads also set the quantity and cost of fuel purchases when combined with equipment efficiency and fuel prices. Building thermal load data affect each of the options evaluated except for peak shaving.

Building and central plant loads were determined via a combination of bottoms-up and top-down approaches. The bottoms-up approach used the Facility Energy Decision System (FEDS) model, which calculated building space heating, space cooling, and service water heating loads for every building currently served by the central energy systems ${ }^{3}$. The top-down approach starts with measured energy consumption for the Fort, each central energy plant, and other subsets of the Fort. The two viewpoints are combined to develop an overall model of Fort energy use that is consistent with actual measured energy use, where available.

Much of the work associated with developing the FEDS-based model of Fort energy demand was based on previous work ${ }^{4}$. Selected building characteristics were updated to reflect information gathered in recent FEMP SavEnergy audits ${ }^{5}$. Central boiler and chiller characteristics were reviewed and modified where better data were found.

Thermal distribution piping maps were reviewed to update the list of buildings served by each of the central plants. The FEDS model was then recalibrated to reflect the improved assumptions for the existing infrastructure.

The FEDS assessment referenced above was conducted prior to the commissioning of a fourth central energy plant at the northern end of the Post. Approximately $10 \%$ of the buildings previously served by CEP \#2 are now served by CEP \#4. This CES Modernization Study is based on the thermal distribution system connections prior to commissioning of the fourth CEP. Thus, while the building loads and thermal distribution losses for buildings served by CES at the Fort have not changed substantially, the building loads and thermal distribution losses associated with CEP \#2 have since been reduced. While this obviously affects the collective loads and costs of any future option(s) for buildings served by CEP \#2, it is not believed to affect the choice of the best option(s) for buildings served by CEP \#2.

\footnotetext{
${ }^{3}$ Facility Energy Decision System User's Guide, Release 5.0. 2002. PNNL-10542, Rev 3. Pacific Northwest National Laboratory. Richland Washington.

${ }^{4}$ Facility Energy Decision System (FEDS) Report for Fort Jackson, South Carolina. July 2004. Parker, G.B., A.E. Solana, D.L. Hadley, and D.R. Dixon. PNNL-14781. Pacific Northwest National Laboratory. Richland, Washington.

${ }^{5}$ FEMP SavEnergy audits were completed in the Fall of 2005 for buildings 1892, 2205, 3215, 4295, 5500, and 11000. These buildings collectively represent about 2.5 million SF of barracks space at Fort Jackson.
} 


\section{Energy Prices}

Electricity and natural gas price assumptions were based on the current electricity tariff and recent natural gas prices coupled with the energy price escalation rates prescribed by the National Institute of Standards and Technology (NIST) for the industrial sector in the South $^{6}$. Fort Jackson is served with electricity by South Carolina Electric \& Gas via Rate 24, Large General Service - Time-of-Use. The specific rates in effect as of June 2006 are summarized in Table 2. Note that during the non-summer months, the on-peak billing demand is the greater of the actual on-peak demand or $80 \%$ of the maximum on-peak demand during the preceding summer months. In other words, an $80 \%$ "ratchet” applies to the non-summer on-peak billing demand.

Table 2. Fort Jackson Electricity Rates

\begin{tabular}{|l|c|}
\hline Summer on-peak demand charge & $\$ 14.58 / \mathrm{kW}$ \\
\hline Non-summer on-peak demand charge & $\$ 10.21 / \mathrm{kW}$ \\
\hline Off-peak demand charge & $\$ 4.40 / \mathrm{kW}$ \\
\hline Summer on-peak energy charge & $\$ 0.05250 / \mathrm{kWh}$ \\
\hline Non-summer on-peak energy charge & $\$ 0.03779 / \mathrm{kWh}$ \\
\hline Off-peak energy charge & $\$ 0.03053 / \mathrm{kWh}$ \\
\hline
\end{tabular}

Recent volatility in natural gas prices warrants extra care in defining an appropriate current price at Fort Jackson that must be coupled with the prescribed NIST escalation rates. The NIST escalation rates for industrial natural gas prices in the South assume a starting price of \$7.37/MMBtu. However, comparison of average industrial natural gas prices with prices paid by Fort Jackson over the last 6 years indicate an average premium of $\$ 0.66 / \mathrm{MMBtu}$ paid by the Fort. Therefore, the initial natural gas price assumed in this study was set to $\$ 7.37+\$ 0.66=\$ 8.03 / \mathrm{MMBtu}$.

\footnotetext{
${ }^{6}$ Energy Price Indices and Discount Factors for Life-Cycle Cost Analysis - April 2006. A.S. Rushing and S.K. Fuller. NISTIR 85-3273-21. National Institute of Standards and Technology. Washington DC.
} 


\section{Central Energy System Characteristics}

Other than the recently constructed CEP \#4 that was not modeled, Fort Jackson is served by CEPs located in Building 2288 (CEP \#1), Building 4333 (CEP \#2), and Building 1699 (CEP \#3). The central energy systems serve approximately 150 buildings with a combined floor area of 3.7 million SF. A complete listing of the buildings served by each of the three systems is provided in Appendix A along with an indication of whether $\mathrm{HW}$, $\mathrm{CW}$, or both are delivered to the building.

Central boiler and chiller characteristics are presented in Table 3. Data collected for the 2004 FEDS assessment were supplemented by information provided by Honeywell, the site energy saving performance contract (ESPC) contractor, Fort Jackson appliance reports and boiler inventory data, and records obtained from Trane and Carrier.

Table 3. Fort Jackson Central Boiler and Chiller Characteristics

\begin{tabular}{|c|c|c|c|c|}
\hline Plant/Building & Equipment & Capacity & Vintage & $\begin{array}{c}\text { Rated } \\
\text { Performance }^{7}\end{array}$ \\
\hline \#1, Bldg 2288 & Cleaver Brooks Boiler, 30 psig water & $\begin{array}{l}\text { 47.293 in/37.7 out } \\
\text { MMBtuh }\end{array}$ & 1966 & 0.797 \\
\hline \#1, Bldg 2288 & Cleaver Brooks Boiler, 30 psig water & $\begin{array}{c}47.293 \mathrm{in} / 37.7 \text { out } \\
\text { MMBtuh }\end{array}$ & 1966 & 0.797 \\
\hline \#1, Bldg 2288 & Cleaver Brooks Boiler, 30 psig water & $25.2 \mathrm{in} / 20.0$ out MMBtuh & 1995 & 0.794 \\
\hline \#1, Bldg 2288 & Trane Centrifugal Chiller, CFC-11 & 1050 tons & 1988 & 0.635 \\
\hline \#1, Bldg 2288 & Trane Centrifugal Chiller, HCFC-123 & 1050 tons & 1988 & 0.687 \\
\hline \#1, Bldg 2288 & Trane Centrifugal Chiller, HCFC-123 & 1050 tons & 1988 & 0.687 \\
\hline \#2, Bldg 4333 & Cleaver Brooks Boiler, 35 psig water & $25.106 \mathrm{in} / 20$ out MMBtuh & 2001 & 0.797 \\
\hline \#2, Bldg 4333 & Cleaver Brooks Boiler, 35 psig water & 25.106 in/20 out MMBtuh & 2001 & 0.797 \\
\hline \#2, Bldg 4333 & Cleaver Brooks Boiler, 35 psig water & 25.106 in/20 out MMBtuh & 2000 & 0.797 \\
\hline \#2, Bldg 4333 & Cleaver Brooks Boiler, 35 psig water & 25.106 in/20 out MMBtuh & 2000 & 0.797 \\
\hline \#2, Bldg 4333 & Cleaver Brooks Boiler, 35 psig water & 25.106 in/20 out MMBtuh & 2000 & 0.797 \\
\hline \#2, Bldg 4333 & Trane Centrifugal Chiller, HCFC-123 & 1200 tons & 1991 & 0.632 \\
\hline \#2, Bldg 4333 & Trane Centrifugal Chiller, HCFC-123 & 1200 tons & 1991 & 0.632 \\
\hline \#2, Bldg 4333 & Trane Centrifugal Chiller, HCFC-123 & 1200 tons & 1991 & 0.632 \\
\hline \#2, Bldg 4333 & Carrier Centrifugal Chiller, HFC-134A & 1000 tons & 1990 & 0.588 \\
\hline \#2, Bldg 4333 & Carrier Centrifugal Chiller, HFC-134A & 1500 tons & 1990 & 0.588 \\
\hline \#3, Bldg 1699 & Cleaver Brooks Boiler, 30 psig water & $\begin{array}{c}16.738 \text { in/13.3 out } \\
\text { MMBtuh }\end{array}$ & 1995 & 0.795 \\
\hline \#3, Bldg 1699 & Cleaver Brooks Boiler, 30 psig water & $\begin{array}{c}16.738 \text { in/13.3 out } \\
\text { MMBtuh }\end{array}$ & 1995 & 0.795 \\
\hline \#3, Bldg 1699 & Cleaver Brooks Boiler, 30 psig water & $\begin{array}{c}16.738 \text { in/13.3 out } \\
\text { MMBtuh }\end{array}$ & 1995 & 0.795 \\
\hline \#3, Bldg 1699 & Trane Centrifugal Chiller, HCFC-123 & 750 tons & 1999 & 0.589 \\
\hline \#3, Bldg 1699 & Trane Centrifugal Chiller, HCFC-123 & 750 tons & 2002 & 0.525 \\
\hline
\end{tabular}

\footnotetext{
${ }^{7}$ The rated performance is the conversion efficiency for boilers and $\mathrm{kW} /$ ton for chillers.
} 
Except for two of the boilers at CEP \#1, all boilers and chillers are less than 20 years old. The average boiler efficiency was assumed to be $75 \%$, or about $5 \%$ less than rated efficiencies to account for part loading and cycling. In contrast, the average chiller efficiency was assumed to be equal to its rated performance because part loading and cycling effects are generally offset by the benefit of lower condenser water temperatures when running at reduced load.

All central boilers are dual-fueled and primarily use natural gas, burning fuel oil only when economics dictates a switch. The boilers operate year-round to provide service hot water as well as meeting the seasonal space heating load. The water-cooled chillers run only during the summer months.

CEP \#1 serves about 75 buildings in the southwest corner of the Fort. CEP \#2 serves about 50 buildings just to the north of CEP \#1 along the west edge of the cantonment area. This plant serves some of the largest buildings on site and its buildings are also more spread out than the buildings served by CEP \#1. Therefore, the loads served by CEP \#2 are greater even though the number of buildings served is less. CEP \#3 is the smallest of the three, serving about 15 buildings in the southeast part of the cantonment area.

Most of the hot water (HW) distribution piping at Fort Jackson is insulated steel installed in shallow concrete trenches. Much of the original piping was replaced in 2002. Exceptions are the piping for about $25 \%$ of the buildings served by CEP \#1, which was replaced in 1985 and an original section of direct-buried piping that serves the hospital area loop from CEP \#2. Another exception is the piping serving CEP \#3, which dates to the construction of this plant in 1986.

Chilled water (CW) piping is a mixture of insulated steel and PVC that is direct buried. Buildings in the 2000 area of CEP \# 1 are generally served by PVC, while buildings in the 3000 area of CEP \#1 and 4000 area of CEP \#2 are generally served by the original steel piping installed in the 1960s. The PVC replacement piping was installed in 1991. CW piping materials associated with buildings served by CEP \#3 and building numbers 5000 and higher are as originally constructed, with vintages dating back to 1980, but the specific construction materials were not identified. 


\section{Decentralization of HW Supply for Space and Service Water Heating}

The replacement of central boilers and HW distribution piping with extended natural gas (NG) piping and building boilers presents an opportunity for significant energy savings from eliminated thermal distribution losses, but the owning and operating costs associated with the two alternative sets of equipment must be carefully considered.

The HW energy leaving the CEPs and delivered to the buildings is not directly measured, so an indirect approach to estimating thermal distribution losses was used. During the summer, the thermal load seen by the CEPs is the sum of distribution losses and service hot water (SHW). Daily NG consumption data are shown in Figure 1 for April through June and August in 2003. July and September data were not available, but should be similar to that shown for June and August. The sum of thermal distribution losses and SHW loads was conservatively assumed to equal the minimum natural gas input for the summer, adjusted for an average boiler conversion efficiency of 75\%. SHW loads estimated by the FEDS model were then subtracted to yield estimates of HW thermal distribution losses. The calculations are summarized in Table 4.

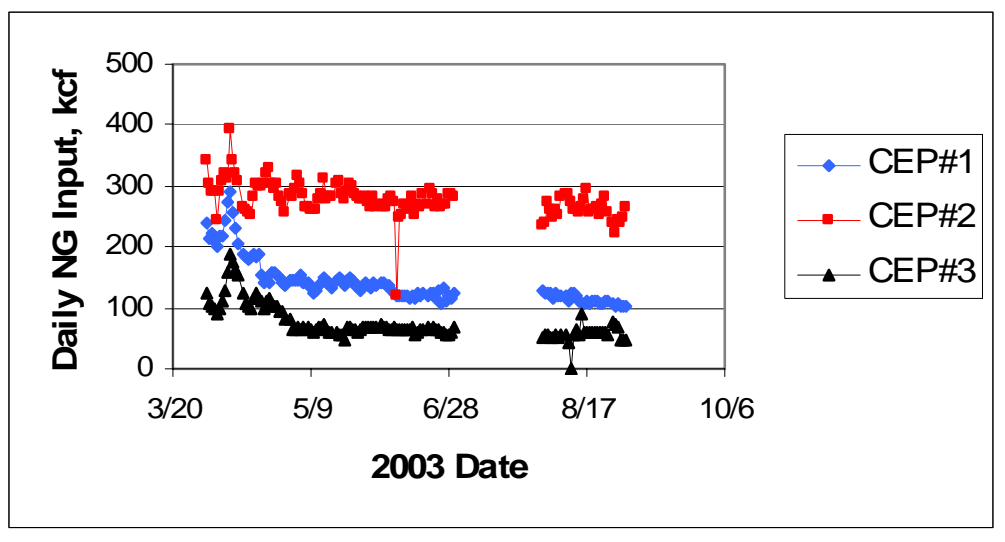

Figure 1. Summer 2003 Daily CEP NG Consumption

Table 4. Estimated HW Distribution Thermal Loss Calculations

\begin{tabular}{|c|c|c|c|c|c|}
\hline CEP & $\begin{array}{c}\text { Minimum } \\
\text { Boiler NG } \\
\text { Input, } \\
\text { kcf/day }\end{array}$ & $\begin{array}{c}\text { Boiler } \\
\text { Efficiency }\end{array}$ & $\begin{array}{c}\text { Minimum } \\
\text { Output, } \\
\text { MMBtu/day }\end{array}$ & $\begin{array}{c}\text { SHW Load, } \\
\text { MMBtu/day }\end{array}$ & $\begin{array}{c}\text { Thermal } \\
\text { Loss, } \\
\text { MMBtu/day }\end{array}$ \\
\hline$\# 1$ & 100 & 0.75 & 77.25 & 23.02 & 54.23 \\
\hline$\# 2$ & 235 & 0.75 & 181.54 & 53.61 & 127.93 \\
\hline$\# 3$ & 50 & 0.75 & 38.63 & 11.73 & 26.89 \\
\hline
\end{tabular}


The installation of building boilers would, for many buildings, require an extension of the existing NG distribution system at the Fort. Maps of the existing NG system were obtained and reviewed. A detailed analysis of the existing capacities and consumption for every NG piping segment was not conducted. Instead, the length of new NG piping required was based on the distance of each building from existing 4-in. NG mains. Small groups of nearly adjacent buildings were allowed to be served by a single branch from a 4-in. main with separate service lines for each building. This approach assumes there is adequate capacity in the existing 4-inch mains to meet the additional building loads, which may be optimistic. However, it also assumes there is inadequate capacity in existing smaller diameter lines closer to the buildings, which may be pessimistic.

Sizing of the new natural gas piping was based on the sum of building space heating and SHW loads estimated by FEDS, 50-psig service, and a peak NG velocity of $20 \mathrm{ft} / \mathrm{sec}$.

NG piping unit costs were based on data presented in Means Mechanical Cost Data 2005 and include trenching, bedding, polyethylene pipe, backfilling, compaction, and pavement replacement. The resulting installed cost estimates were $\$ 8, \$ 9$, and $\$ 10$ per foot for 1.25-in., 2-in., and 3-in. diameter pipe, respectively. Estimates of total new NG piping length and cost are shown in Table 5.

Table 5. New Natural Gas Piping Length and Cost

\begin{tabular}{|c|c|c|}
\hline & $\begin{array}{c}\text { Total } \\
\text { Feet }\end{array}$ & $\begin{array}{c}\text { Total } \\
\text { Cost }\end{array}$ \\
\hline CEP \#1 & 26,639 & $\$ 246,000$ \\
\hline CEP \#2 & 17,229 & $\$ 191,000$ \\
\hline CEP \#3 & 6,815 & $\$ 68,000$ \\
\hline
\end{tabular}

The possible conversion from central to distributed HW production means that maintenance of HW distribution piping would be avoided immediately and replacement of HW distribution piping would be avoided at some point in the future. Maps of the existing systems were obtained and evaluated to determine the lengths and diameters of the piping. The resulting inventory of HW distribution piping is presented in Table 6. The lengths shown are feet of trench, i.e., the combined length of supply and return piping would be double these figures.

Table 6. Fort Jackson HW Distribution Piping

\begin{tabular}{|l|r|r|r|r|r|r|r|r|r|r|r|}
\hline & \multicolumn{9}{|c|}{ Linear Feet of Trench } & & \\
\hline $\begin{array}{l}\text { Pipe } \\
\text { Diameter, } \\
\text { Inches }\end{array}$ & $\mathbf{1}$ & $\mathbf{1 . 2 5}$ & $\mathbf{1 . 5}$ & $\mathbf{2}$ & $\mathbf{2 . 5}$ & $\mathbf{3}$ & $\mathbf{4}$ & $\mathbf{5}$ & $\mathbf{6}$ & $\mathbf{8}$ & Total \\
\hline CEP \#1 & - & 952 & - & 11,070 & 4,277 & 5,109 & 3,781 & 5,586 & 867 & - & 31,642 \\
\hline CEP \#2 & 296 & 931 & - & 7,948 & 598 & 325 & 7,673 & 2,278 & 12,485 & 7,247 & 39,781 \\
\hline CEP \#3 & - & - & - & 200 & 6,178 & 1,088 & 4,258 & - & - & - & 11,724 \\
\hline
\end{tabular}


Replacement HW pipe installed cost assumptions are shown in Table 7. These costs are based on data published by Trane and updated to 2006 dollars $^{8}$. The costs are believed to be representative of direct buried piping, hence roughly representative of replacement costs for piping in existing concrete trench. The installed costs for piping including concrete trenches would be higher.

Table 7. Replacement HW Piping Costs

\begin{tabular}{|c|c|}
\hline $\begin{array}{c}\text { Pipe } \\
\text { Diameter, } \\
\text { Inches }\end{array}$ & $\begin{array}{c}\text { Installed } \\
\text { Cost, \$/foot } \\
\text { of Trench }\end{array}$ \\
\hline 1 & 56 \\
\hline 1.25 & 59 \\
\hline 1.5 & 61 \\
\hline 2 & 67 \\
\hline 2.5 & 72 \\
\hline 3 & 78 \\
\hline 4 & 89 \\
\hline 5 & 99 \\
\hline 6 & 110 \\
\hline 8 & 132 \\
\hline
\end{tabular}

Installed costs for recent Army distribution piping projects were reviewed for comparison. Included were data for projects at Forts Bragg, Gordon, and Jackson, plus Anniston Army Depot and Redstone Arsenal. Total costs per foot ranged from $\$ 84$ to $\$ 497$. However, lack of information regarding piping diameters as well as variation in system design and disposition of existing piping made utilization of the Army data and comparison to the Trane data difficult.

Distributed boiler costs were estimated based on the peak hourly space heating and service water heating loads calculated by FEDS for each building and the boiler material and installation cost equations included in FEDS. Separate boilers were assumed for space and service water heating. The distributed boiler costs directly estimated by FEDS were increased by $80 \%$ to allow for the additional piping, electrical, concrete, steel, instruments, insulation and paint associated with a new boiler in contrast to the retrofit or replacement cost basis estimated directly by the FEDS equations.

Central boiler costs were estimated based on the sum of peak hourly space and service water heating loads calculated by FEDS for all buildings served by each CEP, plus distribution losses. No multiplier was applied to the central boiler costs estimated by the FEDS material and installation cost equations because central boiler capital costs are for a replacement scenario rather than a new construction scenario.

\footnotetext{
${ }^{8}$ Trane Quick Reference for Efficient Chiller Design. May 2000. American Standard, Inc.
} 
Annual maintenance costs were assumed to be $6 \%$ of installed cost for central and distributed boilers, $1 \%$ of installed cost for HW piping and $0.5 \%$ of installed cost for NG piping. The nominal (1\%) maintenance cost for HW piping was adjusted for each system to reflect the differences in the current ages of the distribution systems. In general, annual piping maintenance costs are assumed to increase as the system ages until the system is finally replaced.

The results of the decentralization analysis are summarized in Table 8. Distributed boiler results are shown in the top half of the table and central boiler results on the bottom. Each half shows the capital costs for new equipment, where required, and the annualized costs of capital, operations and maintenance (O\&M), and NG. The analysis is based on the remaining economic life of the HW distribution systems, estimated to average 22 years for CEP \#1, 22 years for CEP \#2, and 9 years for CEP \#3.

Table 8. Decentralization Results

\begin{tabular}{|c|c|c|c|}
\hline & CEP \#1 & CEP \#2 & CEP \#3 \\
\hline \multicolumn{4}{|l|}{$\begin{array}{l}\text { Distributed Boiler Cost } \\
\text { Summary }\end{array}$} \\
\hline \multicolumn{4}{|l|}{ Capital Costs: } \\
\hline Gas Line & $\$ 248,654$ & $\$ 191,018$ & $\$ 68,304$ \\
\hline Boilers & $\$ 1,582,746$ & $\$ 1,601,483$ & $\$ 621,199$ \\
\hline Total & $\$ 1,831,400$ & $\$ 1,792,501$ & $\$ 689,503$ \\
\hline \multicolumn{4}{|l|}{ Annualized Costs: } \\
\hline Gas Line Cap. & $\$ 12,686$ & $\$ 9,746$ & $\$ 3,485$ \\
\hline Gas Line O\&M & $\$ 1,036$ & $\$ 796$ & $\$ 285$ \\
\hline Boilers Cap. & $\$ 80,751$ & $\$ 81,706$ & $\$ 31,693$ \\
\hline Boilers O\&M & $\$ 79,137$ & $\$ 80,074$ & $\$ 31,060$ \\
\hline Gas Cost & $\$ 420,641$ & $\$ 718,823$ & $\$ 233,677$ \\
\hline Total & $\$ 594,251$ & $\$ 891,145$ & $\$ 300,200$ \\
\hline Payback Period, Years & 9.1 & 3.5 & 7.9 \\
\hline \multicolumn{4}{|l|}{ CEP Cost Summary } \\
\hline \multicolumn{4}{|l|}{ Capital Costs: } \\
\hline \multicolumn{4}{|l|}{ Boilers } \\
\hline \multicolumn{4}{|l|}{ Distribution Pipe } \\
\hline \multicolumn{4}{|l|}{ Total } \\
\hline \multicolumn{4}{|l|}{ Annualized Costs: } \\
\hline \multicolumn{4}{|l|}{ Boilers Cap. } \\
\hline Boilers O\&M & $\$ 24,860$ & $\$ 32,693$ & $\$ 14,351$ \\
\hline \multicolumn{4}{|l|}{ Dist Pipe Cap. } \\
\hline Dist Pipe O\&M & $\$ 29,888$ & $\$ 46,974$ & $\$ 16,718$ \\
\hline Gas Cost & $\$ 646,246$ & $\$ 1,238,152$ & $\$ 321,646$ \\
\hline Total & $\$ 700,994$ & $\$ 1,317,819$ & $\$ 352,715$ \\
\hline
\end{tabular}

The results show that immediate conversion from central boilers to distributed boilers is cost effective for all three central energy systems. The cost advantage is greatest for CEP \#2 because it suffers from the greatest distribution losses both in absolute terms and relative to the delivered energy, i.e., it has the least efficient distribution system. 


\section{Cogeneration}

Cogeneration of electricity and thermal energy is an efficient option compared to the separate generation of these latter two energy forms, but it may or may not be a costeffective option. Preliminary screening calculations were conducted for a "best case" scenario where the cogeneration unit operated with an annual availability of $95 \%$ and $100 \%$ of the available thermal energy was utilized to displace HW otherwise generated in central boilers. Both reciprocating engine and combustion turbine cogeneration technologies were considered. The characteristics of the two technologies are compared in Table 9. As can be seen from the table, a reciprocating engine has a lower capital cost and higher electricity conversion efficiency (lower heat rate) than a combustion turbine. The combustion turbine will provide more thermal energy, however, and have lower annual maintenance costs if operated on a 24/7 basis except for required maintenance outages.

Table 9. Cogeneration Technology Characteristics ${ }^{9}$

\begin{tabular}{|l|c|c|}
\hline & $\begin{array}{c}\text { Reciprocating } \\
\text { Engine }\end{array}$ & $\begin{array}{c}\text { Combustion } \\
\text { Turbine }\end{array}$ \\
\hline Net output, kW & 5,000 & 5,000 \\
\hline HHV heat rate, Btu/kWh & 9,213 & 12,590 \\
\hline Thermal recovery, & 0.0033 & 0.0050 \\
MMBtu/hr/kW & 605 & 687 \\
\hline Purchase cost, \$/kW & 365 & 429 \\
\hline Installation cost, \$/kW & 1.2 & 10.9 \\
\hline Fixed maintenance, \$/kW/yr & 8.61 & 5.01 \\
\hline Variable maintenance, \$/MWh & & \\
\hline
\end{tabular}

The results of the economic analysis are shown in Table 10. Neither technology was found to be cost effective, even for this "best case" scenario. At 100\% thermal energy utilization, the annual thermal recovery from either cogeneration technology exceeds the annual HW thermal load for any of the three plants. This is without even considering the seasonal and daily variability in the HW thermal load, which would further erode the thermal utilization fraction. Installing smaller cogeneration units would improve the thermal utilization fraction, but would increase per unit ( $\mathrm{kW}$ and $\mathrm{kWh}$ ) capital and operating costs while further decreasing electrical conversion efficiency. In short, given the current and projected prices for natural gas and electricity, cogeneration is not a costeffective option for Fort Jackson.

\footnotetext{
${ }^{9}$ Gas-Fired Distributed Energy Resources Technology Characterizations. 2003. NREL/TP-620-34783. National Renewable Energy Laboratory. Golden Colorado. (The cost data in this reference were updated to 2006 dollars for presentation in this table.)
} 
Table 10. Cogeneration Economic Results

\begin{tabular}{|l|c|c|}
\hline & $\begin{array}{c}\text { Reciprocating } \\
\text { Engine }\end{array}$ & $\begin{array}{c}\text { Combustion } \\
\text { Turbine }\end{array}$ \\
\hline Installed cost & $\$ 4,850,000$ & $\$ 5,580,000$ \\
\hline Annual Maintenance Cost & $\$ 364,299$ & $\$ 263,133$ \\
\hline $1^{\text {st }}$ Year Fuel Cost & $\$ 3,078,324$ & $\$ 4,206,675$ \\
\hline $1^{\text {st }}$ Year Electricity Savings & $\$ 2,061,927$ & $\$ 2,061,927$ \\
\hline $1^{\text {st }}$ Year Thermal Savings & $\$ 1,484,421$ & $\$ 2,227,522$ \\
\hline Net Present Value & $-\$ 320,413$ & $-\$ 3,666,586$ \\
\hline Payback Period, Years $^{10}$ & 15 & Infinite \\
\hline
\end{tabular}

\footnotetext{
${ }^{10}$ The payback period is based on the year-by-year cumulative cash flows during the 20-year economic life of the project and not the first year annual costs and savings shown in this table. Future declines in the real cost of natural gas allow the reciprocating engine to "payback" after 15 years. Payback is never achieved during the 20 year economic life of the combustion turbine.
} 


\section{Peak Shaving}

As shown in Table 2, the electricity energy charges at Fort Jackson are relatively low, but the electricity demand charges are rather high. In addition, the peak billing demand set during the summer months usually establishes the peak billing demand during the nonsummer months via the $80 \%$ demand "ratchet." This makes peak shaving worthy of consideration.

In contrast to cogeneration, where economics are generally improved by operating as many hours as possible, peak shaving economics are generally improved by operating as little as possible while being sure to operate when the peak billing demand for a month is being set. The trick is being able to predict when the peak billing demands will occur and to be operating during those hours.

For the electricity rates and billing demand rules at Fort Jackson, it's most important to reduce the peak demand seen during the four summer months (June through September) because that establishes the minimum billing demand in the subsequent eight nonsummer months. Additional demand charge savings will accrue by reducing the peak demand during the other three summer months (whichever three are not setting the peak demand for the entire summer) and (for a typical year) reducing the peak demand during May and October. Analysis of recent monthly billing data for the Fort indicated that billing demands for May and October were set by the actual demands for those months rather than the ratchet. The billing demands for November through April were invariably set by the ratchet, so the maximum demand charge savings would require operation during the peak demand setting hours of May through October.

The economic analysis examined 1-MW and 5-MW reciprocating engine generators. Although the economics of a 5-MW unit are a little better than a 1-MW unit, the economic results do not consider the risk of a single larger unit compared to multiple smaller units. Whether through negligence or misfortune, failure to operate when the peak demand for the summer is being set will cut the potential annual demand savings in half. Thus, multiple smaller units are recommended to reduce this risk. Reciprocating engine characteristics are shown in Table 11. Purchase and installation costs are less than for the cogeneration application because no thermal recovery equipment is required. The lower purchase cost (per $\mathrm{kW}$ ) for the smaller unit is probably driven by the greater abundance of units in this size range, which benefits manufacturing economies-of-scale and competition among vendors. 
Table 11. Peak Shaving Technology Characteristics ${ }^{11}$

\begin{tabular}{|l|c|c|}
\hline & $\begin{array}{c}\text { Reciprocating } \\
\text { Engine }\end{array}$ & $\begin{array}{c}\text { Reciprocating } \\
\text { Engine }\end{array}$ \\
\hline Net output, $\mathrm{kW}$ & 5,000 & 1,000 \\
\hline HHV heat rate, Btu/kWh & 9,213 & 10,035 \\
\hline Purchase cost, $\$ / \mathrm{kW}$ & 561 & 512 \\
\hline Installation cost, $/ \mathrm{kW}$ & 196 & 273 \\
\hline Fixed maintenance, $\$ / \mathrm{kW} / \mathrm{yr}$. & 1.2 & 4.36 \\
\hline Variable maintenance, $\$ / \mathrm{MWh}$ & 8.61 & 9.27 \\
\hline
\end{tabular}

The results of the peak shaving economic analysis are presented in Table 12. Results are presented for three different assumptions for the number of operating hours per year. The analysis assumes the peak demand is reduced by the generator's net output for May through October, thus achieving the maximum possible demand charge savings for all three annual operating hour assumptions. The three operating hour assumptions were evaluated because of the uncertain number of hours a generator would have to be operated to achieve the maximum demand charge savings. The number of operating hours required to achieve the maximum demand charge savings will depend on the sharpness of the monthly peak demands and the ability to predict when the peak demand may likely occur. The operating hours investigated were believed to cover the likely range. The results show that peak shaving would be cost effective at Fort Jackson for all of the conditions evaluated, with relatively little degradation in economics as the presumed number of annual operating hours is increased from 200 to 600 or if multiple 1MW engines are used in lieu of a single larger unit.

Table 12. Peak Shaving Economic Results

\begin{tabular}{|l|c|c|c|c|c|c|}
\hline & \multicolumn{3}{|c|}{ 5-MW Engine } & \multicolumn{3}{c|}{ 1-MW Engine } \\
\hline $\begin{array}{l}\text { Annual Operating } \\
\text { Hours }\end{array}$ & 200 & 400 & 600 & 200 & 400 & 600 \\
\hline Installed Cost & $\$ 3,785,000$ & $\$ 3,785,000$ & $\$ 3,785,000$ & $\$ 785,000$ & $\$ 785,000$ & $\$ 785,000$ \\
\hline $\begin{array}{l}\text { Annual Maintenance } \\
\text { Cost }\end{array}$ & $\$ 14,606$ & $\$ 23,217$ & $\$ 31,828$ & $\$ 6,213$ & $\$ 8,066$ & $\$ 9,919$ \\
\hline $1^{\text {st }}$ Year Fuel Cost & $\$ 73,981$ & $\$ 147,961$ & $\$ 221,941$ & $\$ 16,116$ & $\$ 32,232$ & $\$ 48,349$ \\
\hline $\begin{array}{l}1^{\text {st }} \text { Year Electricity } \\
\text { Savings }\end{array}$ & $\$ 686,337$ & $\$ 733,933$ & $\$ 781,530$ & $\$ 137,267$ & $\$ 146,787$ & $\$ 156,306$ \\
\hline Net Present Value & $\$ 4,208,471$ & $\$ 3,911,563$ & $\$ 3,614,653$ & 750,361 & 674,880 & 599,399 \\
\hline $\begin{array}{l}\text { Payback Period, } \\
\text { Years }\end{array}$ & 7 & 7 & 7 & 7 & 8 & 8 \\
\hline
\end{tabular}

\footnotetext{
${ }^{11}$ Gas-Fired Distributed Energy Resources Technology Characterizations. 2003. NREL/TP-620-34783. National Renewable Energy Laboratory. Golden Colorado. (The cost data in this reference were updated to 2006 dollars for presentation in this table.)

${ }^{12}$ The payback period is based on the year-by-year cumulative cash flows during the 20-year economic life of the project and not the first year annual costs and savings shown in this table.
} 


\section{Chill Thermal Energy Storage}

Chill thermal energy storage (TES), also known as cool storage, chill storage, or cool thermal storage, can be used to significantly reduce electricity costs by allowing energyintensive, electrically-driven cooling equipment to be predominantly operated during offpeak hours when electricity rates are lower and chiller performance is better. Fort Jackson, with its high, ratcheted demand charges, presents conditions where cool storage might likely be attractive. In fact, a chilled water storage tank already exists at CEP \#2, but mechanical problems with its internal piping need repairing to make it operable again. In this study, the cost effectiveness of installing new chilled water storage systems at CEP \#1 and CEP \#3 and fixing the existing chilled water storage system at CEP \#2 were evaluated.

As suggested above, the primary benefit from operating a chill storage system at Fort Jackson is to minimize or eliminate chiller operation during the on-peak periods, which reduces the Fort's peak demand charges. Moving chiller operation from on-peak to offpeak periods also reduces electricity energy charges. Additional advantages are improved chiller performance from increased operation at night when condenser cooling water temperatures are usually lower and by more even chiller loading. These performance advantages are at least partly offset by thermal losses (actually heat gain) in the chilled water storage tank. On net, any performance advantage or disadvantage with chill storage is small; the primary impact is to reduce electricity costs by substituting less expensive off-peak power for more expensive on-peak power. The electricity cost savings must be compared to the cost of installing and maintaining the chilled water storage system to determine overall cost effectiveness.

Cool storage systems are best evaluated by examining the impacts on chiller loads on an hourly basis. Hourly analysis allows more accurate evaluation of the benefits and allows checking to ensure that adequate chiller capacity exists during off-peak hours to charge storage while still meeting off-peak cooling loads. Hourly analysis also allows evaluation of variation in chiller performance from variation in condenser chilled water temperature and chiller part-load performance.

Hourly chiller loads for each of the CEPs were derived from hourly building cooling loads simulated by FEDS for selected design days and then extrapolated to every hour of the year via regression analysis. Thermal distribution losses were added to the collective building cooling load to estimate the CEP cooling load. The chilled water thermal distribution efficiencies were assumed to be $85 \%$ for CEP \#1 and CEP \#2, and $90 \%$ for the smaller distribution system associated with CEP \#3.

Chiller performance was based on the rated kW/ton figures shown in Table 3, with adjustments for condenser water temperature and part-loading. For modeling purposes, chiller dispatch order at each of the three CEPs was assumed to start with the most efficient chiller, followed by the next most efficient chiller and so on until the load for that hour was met. 
Chilled water storage system costs were based on budget estimates received from Chicago Bridge and Iron (CBI) for a range of tank sizes. An additional 15\% was added to the CBI estimates to account for miscellaneous field items outside of the CBI scope. The resultant total cost estimates were then consistent with figures reported for a large chilled water storage system installed at a VA hospital in Dallas, Texas ${ }^{13}$. Estimated storage system repair costs for CEP \# 2 were provided by Fort Jackson staff.

For CEP \#1 and CEP \#3 the storage capacity was varied until the maximum net present value of the project was found. For CEP \#2, the storage capacity was set at its existing size. The impacts on demand and energy costs were calculated for the various rate periods and the net effect for the entire year. The results are presented in Tables 13-15. A new chill storage system was found to be cost effective, but barely so, for CEP \#1 and not cost effective for CEP \#3, where the loads are much less. Repairing the existing chill storage system at CEP \#2 was very cost effective. The energy savings details show how on-peak period costs have declined while off-peak period costs have risen. As expected, demand related savings are most important, but energy related savings are significant.

Table 13. CEP Thermal Energy Storage Capacities

\begin{tabular}{|c|c|}
\hline CEP & Capacity, Ton-Hours \\
\hline$\# 1$ & 21,400 \\
\hline$\# 2$ & 16,800 \\
\hline$\# 3$ & 5,900 \\
\hline
\end{tabular}

Table 14. Chill Thermal Energy Storage Annual Electricity Savings

\begin{tabular}{|l|r|r|r|}
\hline \multicolumn{1}{|c|}{ Rate Period } & \multicolumn{1}{c|}{ CEP \#1 } & \multicolumn{1}{c|}{ CEP \#2 } & \multicolumn{1}{c|}{ CEP \#3 } \\
\hline Summer On-Peak Demand & $\$ 118,944$ & $\$ 105,853$ & $\$ 31,350$ \\
\hline Summer Off-Peak Demand & $-\$ 34,416$ & $-\$ 29,434$ & $-\$ 8,680$ \\
\hline Shoulder On-Peak Demand & $\$ 32,302$ & $\$ 29,404$ & $\$ 8,494$ \\
\hline Shoulder Off-Peak Demand & $-\$ 10,915$ & $-\$ 6,199$ & $-\$ 1,828$ \\
\hline Winter On-Peak Demand & $\$ 96,906$ & $\$ 88,212$ & $\$ 25,483$ \\
\hline Winter Off-Peak Demand & $\$ 0$ & $\$ 0$ & $\$ 0$ \\
\hline Summer Weekday On-Peak Energy & $\$ 49,353$ & $\$ 43,091$ & $\$ 13,402$ \\
\hline Summer Weekday Off-peak Energy & $-\$ 27,485$ & $-\$ 22,988$ & $-\$ 7,870$ \\
\hline Shoulder Weekday On-Peak Energy & $\$ 11,024$ & $\$ 11,916$ & $\$ 3,410$ \\
\hline Shoulder Weekday Off-peak Energy & $-\$ 7,542$ & $-\$ 7,668$ & $-\$ 2,062$ \\
\hline Winter Weekday On-Peak Energy & $\$ 3,146$ & $\$ 3,756$ & $\$ 902$ \\
\hline Winter Weekday Off-peak Energy & $-\mathbf{\$ 2 , 0 4 4}$ & $-\mathbf{\$ 2 , 5 5 3}$ & $-\$ 581$ \\
\hline Weekend Off-peak Energy & $\$ 0$ & $\$ 0$ & $\$ 0$ \\
\hline Net Electricity Savings & $\mathbf{\$ 2 2 9 , 2 7 4}$ & $\mathbf{\$ 2 1 3 , 3 8 8}$ & $\mathbf{\$ 6 2 , 0 1 9}$ \\
\hline
\end{tabular}

\footnotetext{
${ }^{13}$ Thermal Energy Storage Energy Efficiency Fact Sheet. 2003. Washington State University Cooperative Extension Energy Program.
} 
Table 15. Chill Thermal Energy Storage Costs and Economics

\begin{tabular}{|l|r|r|r|}
\hline & \multicolumn{1}{|c|}{ CEP \#1 } & \multicolumn{1}{|c|}{ CEP \#2 } & \multicolumn{1}{c|}{ CEP \#3 } \\
\hline Capital Cost & $\$ 2,587,606$ & $\$ 524,700$ & $\$ 1,105,318$ \\
\hline O\&M Cost/Yr & $\$ 22,307$ & $\$ 20,000$ & $\$ 9,529$ \\
\hline Net Present Value & $\$ 87,302$ & $\$ 1,975,999$ & $-\$ 434,035$ \\
\hline Payback Period, Years & 12.5 & 2.7 & 21.1 \\
\hline
\end{tabular}


APPENDIX A

Buildings Serviced by Central Energy Plants 


\section{Appendix A Buildings Served by Central Energy Plants}

\begin{tabular}{|c|c|c|}
\hline \multicolumn{3}{|c|}{ CEP \#1 Bldg 2288} \\
\hline Bldg \# & HW & $\mathbf{C W}$ \\
\hline 2009 & $\mathrm{X}$ & $\mathrm{x}$ \\
\hline 2075 & $\mathrm{X}$ & \\
\hline 2078 & $\mathrm{X}$ & \\
\hline 2079 & $\mathrm{X}$ & \\
\hline 2100 & $\mathrm{X}$ & $\mathrm{x}$ \\
\hline 2119 & $\mathrm{x}$ & $\mathrm{x}$ \\
\hline 2139 & $\mathrm{x}$ & $\mathrm{x}$ \\
\hline 2159 & $\mathrm{x}$ & $\mathrm{x}$ \\
\hline 2179 & $\mathrm{x}$ & $\mathrm{x}$ \\
\hline 2200 & $\mathrm{x}$ & $\mathrm{x}$ \\
\hline 2205 & $\mathrm{x}$ & $\mathrm{x}$ \\
\hline 2210 & $\mathrm{x}$ & $\mathrm{x}$ \\
\hline 2215 & $\mathrm{x}$ & $\mathrm{x}$ \\
\hline 2225 & $\mathrm{x}$ & $\mathrm{x}$ \\
\hline 2230 & $\mathrm{x}$ & $\mathrm{x}$ \\
\hline 2235 & $\mathrm{x}$ & $\mathrm{x}$ \\
\hline 2240 & $\mathrm{x}$ & $\mathrm{x}$ \\
\hline 2245 & $\mathrm{x}$ & $\mathrm{x}$ \\
\hline 2250 & $\mathrm{x}$ & $\mathrm{x}$ \\
\hline 2253 & $\mathrm{x}$ & $\mathrm{x}$ \\
\hline 2255 & $\mathrm{x}$ & $\mathrm{x}$ \\
\hline 2260 & $\mathrm{x}$ & $\mathrm{x}$ \\
\hline 2265 & $\mathrm{x}$ & $\mathrm{x}$ \\
\hline 2270 & $\mathrm{x}$ & $\mathrm{x}$ \\
\hline 2275 & $\mathrm{x}$ & $\mathrm{x}$ \\
\hline 2280 & $\mathrm{x}$ & $\mathrm{x}$ \\
\hline 2285 & $\mathrm{x}$ & $\mathrm{x}$ \\
\hline 2300 & $\mathrm{x}$ & $\mathrm{x}$ \\
\hline 2310 & $\mathrm{x}$ & $\mathrm{x}$ \\
\hline 2320 & $\mathrm{x}$ & $\mathrm{x}$ \\
\hline 2335 & $\mathrm{x}$ & $\mathrm{x}$ \\
\hline 2340 & $\mathrm{x}$ & $\mathrm{x}$ \\
\hline 2360 & $\mathrm{x}$ & $\mathrm{x}$ \\
\hline 2370 & $\mathrm{x}$ & $\mathrm{x}$ \\
\hline 2375 & $\mathrm{x}$ & $\mathrm{x}$ \\
\hline 2395 & $\mathrm{x}$ & $\mathrm{x}$ \\
\hline 2400 & $\mathrm{x}$ & $\mathrm{x}$ \\
\hline 2435 & $\mathrm{x}$ & $\mathrm{x}$ \\
\hline 2442 & $\mathrm{x}$ & $\mathrm{x}$ \\
\hline 2446 & $\mathrm{x}$ & $\mathrm{x}$ \\
\hline 2447 & $\mathrm{x}$ & $\mathrm{x}$ \\
\hline 2449 & $\mathrm{x}$ & $\mathrm{x}$ \\
\hline 2453 & $\mathrm{x}$ & $\mathrm{x}$ \\
\hline 2460 & $\mathrm{x}$ & $\mathrm{x}$ \\
\hline 2461 & $\mathrm{x}$ & $\mathrm{x}$ \\
\hline
\end{tabular}

A.1 


\begin{tabular}{|c|c|c|}
\hline \multicolumn{3}{|c|}{ CEP \#1 Bldg 2288} \\
\hline Bldg \# & HW & $\mathbf{C W}$ \\
\hline 2462 & $\mathrm{X}$ & $\mathrm{X}$ \\
\hline 2463 & $\mathrm{x}$ & $\mathrm{x}$ \\
\hline 2464 & $\mathrm{x}$ & \\
\hline 2466 & $\mathrm{x}$ & $\mathrm{X}$ \\
\hline 2467 & $\mathrm{x}$ & $\mathrm{x}$ \\
\hline 2468 & $\mathrm{x}$ & $\mathrm{x}$ \\
\hline 3200 & $\mathrm{x}$ & $\mathrm{x}$ \\
\hline 3205 & $\mathrm{X}$ & $\mathrm{x}$ \\
\hline 3210 & $X$ & $\mathrm{x}$ \\
\hline 3215 & $\mathrm{x}$ & $\mathrm{x}$ \\
\hline 3216 & $\mathrm{x}$ & $\mathrm{x}$ \\
\hline 3220 & $\mathrm{x}$ & $\mathrm{x}$ \\
\hline 3225 & $\mathrm{x}$ & $\mathrm{x}$ \\
\hline 3230 & $\mathrm{x}$ & $\mathrm{x}$ \\
\hline 3235 & $\mathrm{x}$ & $\mathrm{x}$ \\
\hline 3240 & $\mathrm{x}$ & $\mathrm{x}$ \\
\hline 3250 & $\mathrm{x}$ & $\mathrm{x}$ \\
\hline 3255 & $\mathrm{x}$ & $\mathrm{x}$ \\
\hline 3260 & $X$ & $\mathrm{x}$ \\
\hline 3265 & $\mathrm{X}$ & $\mathrm{x}$ \\
\hline 3270 & $\mathrm{X}$ & $\mathrm{X}$ \\
\hline 3275 & $\mathrm{x}$ & $\mathrm{x}$ \\
\hline 3276 & $\mathrm{X}$ & $\mathrm{x}$ \\
\hline 3280 & $\mathrm{X}$ & $\mathrm{x}$ \\
\hline 3285 & $\mathrm{X}$ & $\mathrm{x}$ \\
\hline 3290 & $\mathrm{x}$ & $\mathrm{x}$ \\
\hline 3295 & $\mathrm{x}$ & $\mathrm{x}$ \\
\hline 3296 & $\mathrm{x}$ & \\
\hline 3300 & $\mathrm{X}$ & $\mathrm{x}$ \\
\hline 3319 & $\mathrm{x}$ & $\mathrm{x}$ \\
\hline 3320 & $\mathrm{x}$ & $\mathrm{x}$ \\
\hline 3330 & $\mathrm{X}$ & $\mathrm{x}$ \\
\hline 3359 & $\mathrm{x}$ & $\mathrm{x}$ \\
\hline 3360 & $\mathrm{x}$ & $\mathrm{x}$ \\
\hline 3390 & $\mathrm{x}$ & $\mathrm{x}$ \\
\hline 3392 & $\mathrm{X}$ & \\
\hline
\end{tabular}

\begin{tabular}{|c|c|c|}
\hline \multicolumn{3}{|c|}{ CEP \#2 Bldg 4333} \\
\hline Bldg \# & HW & $\mathbf{C W}$ \\
\hline 3392 & & $\mathrm{x}$ \\
\hline 4149 & $\mathrm{x}$ & $\mathrm{x}$ \\
\hline 4159 & $\mathrm{x}$ & $\mathrm{x}$ \\
\hline 4169 & $\mathrm{x}$ & $\mathrm{x}$ \\
\hline 4200 & $\mathrm{X}$ & $\mathrm{x}$ \\
\hline 4205 & $\mathrm{x}$ & $\mathrm{x}$ \\
\hline 4210 & $\mathrm{x}$ & $\mathrm{x}$ \\
\hline 4215 & $\mathrm{x}$ & $\mathrm{x}$ \\
\hline 4220 & $\mathrm{x}$ & $\mathrm{x}$ \\
\hline
\end{tabular}

A. 2 


\begin{tabular}{|c|c|c|}
\hline \multicolumn{3}{|c|}{ CEP \#2 Bldg 4333} \\
\hline Bldg \# & HW & $\mathbf{C W}$ \\
\hline 4225 & $\mathrm{X}$ & $\mathrm{x}$ \\
\hline 4230 & $\mathrm{X}$ & $\mathrm{X}$ \\
\hline 4235 & $\mathrm{x}$ & $\mathrm{x}$ \\
\hline 4243 & $\mathrm{x}$ & $\mathrm{x}$ \\
\hline 4250 & $\mathrm{X}$ & $\mathrm{x}$ \\
\hline 4255 & $\mathrm{x}$ & $\mathrm{x}$ \\
\hline 4265 & $\mathrm{x}$ & $\mathrm{x}$ \\
\hline 4270 & $\mathrm{X}$ & $\mathrm{x}$ \\
\hline 4275 & $\mathrm{x}$ & $\mathrm{x}$ \\
\hline 4280 & $\mathrm{x}$ & $\mathrm{x}$ \\
\hline 4285 & $\mathrm{x}$ & $\mathrm{X}$ \\
\hline 4290 & $\mathrm{x}$ & $\mathrm{x}$ \\
\hline 4295 & $\mathrm{x}$ & $\mathrm{x}$ \\
\hline 4310 & $\mathrm{x}$ & $\mathrm{x}$ \\
\hline 4323 & $\mathrm{x}$ & $\mathrm{x}$ \\
\hline 4330 & $\mathrm{x}$ & $\mathrm{x}$ \\
\hline 4340 & $\mathrm{x}$ & $\mathrm{x}$ \\
\hline 4350 & $\mathrm{x}$ & $\mathrm{x}$ \\
\hline 4360 & $\mathrm{x}$ & $\mathrm{x}$ \\
\hline 4380 & $\mathrm{x}$ & $\mathrm{x}$ \\
\hline 4392 & $\mathrm{x}$ & $\mathrm{x}$ \\
\hline 4394 & $\mathrm{x}$ & $\mathrm{x}$ \\
\hline 4420 & $\mathrm{x}$ & $\mathrm{x}$ \\
\hline 4482 & $\mathrm{x}$ & $\mathrm{x}$ \\
\hline 4575 & $\mathrm{x}$ & $\mathrm{x}$ \\
\hline 4580 & $\mathrm{x}$ & $\mathrm{x}$ \\
\hline 4581 & $\mathrm{x}$ & $\mathrm{X}$ \\
\hline 4590 & $\mathrm{x}$ & $\mathrm{X}$ \\
\hline 4600 & $\mathrm{x}$ & $\mathrm{x}$ \\
\hline 5330 & $\mathrm{X}$ & $\mathrm{x}$ \\
\hline 5385 & $\mathrm{X}$ & $\mathrm{X}$ \\
\hline 5422 & $\mathrm{x}$ & $\mathrm{x}$ \\
\hline 5432 & $\mathrm{x}$ & $\mathrm{x}$ \\
\hline 5450 & $\mathrm{x}$ & $\mathrm{x}$ \\
\hline 5475 & $\mathrm{x}$ & $\mathrm{X}$ \\
\hline 5482 & $\mathrm{x}$ & $\mathrm{x}$ \\
\hline 5483 & $\mathrm{x}$ & $\mathrm{x}$ \\
\hline 5489 & $\mathrm{X}$ & $\mathrm{X}$ \\
\hline 5499 & $\mathrm{X}$ & $\mathrm{X}$ \\
\hline 5500 & $\mathrm{x}$ & $\mathrm{x}$ \\
\hline 9475 & $\mathrm{X}$ & $\mathrm{X}$ \\
\hline 11000 & $\mathrm{X}$ & $\mathrm{X}$ \\
\hline 12000 & $\mathrm{X}$ & $\mathrm{X}$ \\
\hline
\end{tabular}

\begin{tabular}{|c|c|c|}
\hline \multicolumn{3}{|c|}{ CEP\#3 Bldg 1699 } \\
\hline Bldg \# & HW & CW \\
\hline 1867 & $\mathrm{X}$ & $\mathrm{x}$ \\
\hline 1872 & $\mathrm{x}$ & $\mathrm{x}$ \\
\hline 1875 & $\mathrm{x}$ & $\mathrm{x}$ \\
\hline 1877 & $\mathrm{x}$ & $\mathrm{x}$ \\
\hline
\end{tabular}

A. 3 


\begin{tabular}{|c|c|c|}
\hline \multicolumn{3}{|c|}{ CEP\#3 BIdg 1699 } \\
\hline Bldg \# & HW & CW \\
\hline 1880 & $\mathrm{x}$ & $\mathrm{x}$ \\
\hline 1889 & $\mathrm{x}$ & $\mathrm{x}$ \\
\hline 1890 & $\mathrm{x}$ & $\mathrm{x}$ \\
\hline 1892 & $\mathrm{x}$ & $\mathrm{x}$ \\
\hline 1895 & $\mathrm{x}$ & $\mathrm{x}$ \\
\hline 1897 & $\mathrm{x}$ & $\mathrm{x}$ \\
\hline 2601 & $\mathrm{x}$ & $\mathrm{x}$ \\
\hline 2602 & $\mathrm{x}$ & $\mathrm{x}$ \\
\hline 2603 & $\mathrm{x}$ & $\mathrm{x}$ \\
\hline 2604 & $\mathrm{x}$ & $\mathrm{x}$ \\
\hline 2605 & $\mathrm{x}$ & $\mathrm{x}$ \\
\hline 2785 & $\mathrm{x}$ & $\mathrm{x}$ \\
\hline
\end{tabular}

A. 4 